\title{
POLA HUBUNGAN HUKUM DALAM PEMANFAATAN TANAH ULAYAT DI SUMATERA BARAT*
}

\author{
Kurnia Warman ${ }^{* *}$ dan Hengki Andora ${ }^{* * *}$ \\ Bagian Hukum Agraria dan Bagian Hukum Administrasi Negara Fakultas Hukum \\ Universitas Andalas, Padang \\ Kampus Limau Manis, Padang, Sumatera Barat 25163
}

\begin{abstract}
Communal land is the identity of indigenous communities whose existence is protected by the Constitution. Customary land is not only used for the purposes of indigenous peoples, but also exploited by the outsiders. This study examines how the pattern of the legal relationship between the indigenous people and to outsiders by using socio-legal research. This study was conducted in West Sumatera by limiting the study to the four natural resource sectors, namely plantations, water resources, mining and forestry. The results of this study indicate that the legal relationships that are not obvious to trigger disputes between indigenous people and outsiders.
\end{abstract}

Keywords: legal relationship, utilization, communal land.

\section{Intisari}

Tanah ulayat merupakan identitas masyarakat hukum adat yang diakui dan dilindungi keberadaannya oleh UUD 1945. Tanah ulayat tidak hanya digunakan untuk keperluan masyarakat hukum adat, namun juga dimanfaatkan oleh pihak luar. Penelitian ini mengkaji bagaimana pola hubungan hukum antara masyarakat hukum adat dengan pihak luar dalam pemanfaatan tanah ulayat dengan menggunakan pendekatan yuridis empiris. Penelitian ini dilakukan di Sumatera Barat dengan membatasi kajian pada 4 (empat) sektor sumberdaya alam, yaitu perkebunan, sumberdaya air, pertambangan dan kehutanan. Hasil penelitian ini menunjukkan bahwa ketidakjelasan hubungan hukum menjadi pemicu munculnya sengketa antara masyarakat hukum adat dengan pihak luar di dalam pemanfaatan tanah ulayat.

Kata Kunci: hubungan hukum, pemanfaatan, tanah ulayat.

\section{Pokok Muatan}

A. Latar Belakang Masalah 367

B. Metode Penelitian

C. Hasil Penelitian dan Pembahasan

1. Pola Hubungan Hukum dalam Pemanfaatan Tanah Ulayat untuk Usaha Perkebunan 370

2. Pola Hubungan Hukum dalam Pemanfaatan Tanah Ulayat untuk Usaha Pengelolaan Sumber Daya Air 371

3. Pola Hubungan Hukum dalam Pemanfaatan Tanah Ulayat untuk Usaha Pertambangan ............ 373

4. Pola Hubungan Hukum dalam Pemanfaatan Tanah Ulayat untuk Usaha Kehutanan ................ 375

D. Kesimpulan

\footnotetext{
Artikel ini dibuat berdasarkan hasil penelitian dari Skema Penelitian Strategis Nasional, dalam kelompok Integrasi Nasional dan Harmoni Sosial, yang didanai oleh Direktorat Jenderal Pendidikan Tinggi Kementerian Pendidikan dan Kebudayaan RI Tahun 2013.

** Alamat korespondensi: kurnia_warman@yahoo.com

*** Alamat korespondensi: hengkiandora@yahoo.co.id
} 


\section{A. Latar Belakang Masalah}

Bagi masyarakat hukum adat (MHA) di Minangkabau, tanah merupakan aset yang sangat berharga. Tidak hanya sebagai tempat untuk menjalani rutinitas kehidupan sehari-hari, tanah juga menjadi simbol dan prestise yang menunjukkan eksistensi suatu suku atau kaum di Minangkabau. Adagium mereka menyatakan bahwa tidak sejengkal tanah pun di Minangkabau yang tidak ada pemiliknya. ${ }^{1}$ Tanah-tanah tersebut ada yang berstatus sebagai ulayat nagari, ulayat suku, atau ulayat kaum. ${ }^{2}$

Jika diumpamakan, hubungan tanah dengan eksistensi suatu suku atau kaum diibaratkan seperti dua sisi mata uang yang tidak terpisahkan satu sama lainnya. Hal ini tidak terlepas dari susunan MHA di Minangkabau yang genealogis-teritorial. ${ }^{3}$ Masyarakatnya diikat berdasarkan garis keturunan dan wilayah adat. MHA hidup berkelompokkelompok berdasarkan garis kekerabatan dan mempunyai wilayah yang tertentu. Dalam wilayah ini, masyarakat membentuk struktur adat serta mempunyai harta kekayaan dalam bentuk tanah ulayat yang dimiliki secara komunal oleh MHA. Berdasarkan pola susunan masyarakat ini dapat disimpulkan bahwa eksistensi suatu suku atau kaum di Minangkabau berbanding lurus dengan keberadaan tanah ulayat suku atau kaumnya. Dalam konteks demikian, keberadaan suku atau kaum di Nagari akan tetap kukuh bilamana tanah yang menjadi ulayatnya masih tetap utuh.

Oleh karena itu, proses peralihan tanah ulayat amat rumit di Minangkabau. Dalam Hukum Adat Minangkabau, tanah ulayat tidak boleh dijual selama-lamanya kepada pihak lain. ${ }^{4}$ Kalaupun tanah tersebut mau dialihkan, peralihannya hanya bersifat sementara dan hal itu pun tidak boleh dilakukan secara serampangan. Tanah ulayat hanya diperkenankan untuk digadaikan dalam kondisi tertentu saja, yaitu: mayik tabujua di tangah rumah (mayat terbujur di tengah rumah); gadih gadang alun balaki (perempuan dewasa yang belum bersuami); rumah gadang katirisan (rumah gadang ketirisan); dan mambangkik batang tarandam (membangkitkan batang terendam). ${ }^{5}$

Hak ulayat sebagai hak yang melekat pada masyarakat hukum adat secara konstitusional diakui dan dihormati keberadaannya dalam UndangUndang Dasar Negara Republik Indonesia Tahun 1945 (UUD NRI Tahun 1945). Pasal 18B ayat (2) UUD NRI Tahun 1945 dengan tegas menyatakan bahwa negara mengakui dan menghormati kesatuan-kesatuan masyarakat hukum adat beserta hak-hak tradisionalnya sepanjang masih hidup dan sesuai dengan perkembangan masyarakat dan prinsip Negara Kesatuan Republik Indonesia, yang diatur dalam Undang-Undang. Kemudian, Pasal 28I ayat (3) juga menyebutkan bahwa identitas budaya dan hak masyarakat tradisional dihormati selaras dengan perkembangan zaman dan peradaban. Jika dicermati ketentuan UUD NRI Tahun 1945 di atas, negara mengakui keberadaan MHA beserta dengan hak-hak yang melekat padanya. Namun, pengakuan tersebut harus memenuhi persyaratan tertentu, yaitu: (1) sepanjang masih hidup; (2) sesuai dengan perkembangan masyarakat; (3) sesuai dengan prinsip Negara Kesatuan Republik Indonesia; dan (4) diatur dalam Undang-Undang.

Dalam UU No. 5 Tahun 1960 tentang Peraturan Dasar Pokok-Pokok Agraria (UUPA), pengakuan terhadap hak ulayat juga disertai dengan persyaratan. Setidaknya ada dua persyaratan yang harus terpenuhi, yaitu mengenai eksistensinya dan mengenai pelaksanaannya. Hak ulayat diakui eksistensinya, bilamana menurut kenyataannya di lingkungan kesatuan masyarakat hukum adat tertentu yang bersangkutan memang masih ada. Jika ternyata masih ada, pelaksanaannya harus sedemikian rupa

Lihat dalam Alfan Miko (Ed.), 2006, Pemerintahan Nagari dan Tanah Ulayat, Andalas University Press, Padang, hlm. 187. Ibid, hlm. 150

Lihat dalam Soleman B. Taneko, 1987, Hukum Adat: Suatu Pengantar Awal dan Prediksi Masa Mendatang, Eresco, Bandung, hlm. 41-42. Lihat dalam Datoek Toeah, 1986, Tambo Alam Minangkabau, Pustaka Indonesia, Bukittinggi, hlm. 239.

Ibid, hlm. 243. 
sehingga sesuai dengan kepentingan nasional dan negara, yang berdasar atas persatuan bangsa serta tidak boleh bertentangan dengan Undang-Undang dan peraturan-peraturan lain yang lebih tinggi. ${ }^{6}$ Terkait dengan pengaturan hak ulayat, Boedi Harsono mengemukakan pendapat:

Sengaja UUPA tidak mengadakan pengaturan dalam bentuk peraturan perundang-undangan mengenai hak ulayat, dan membiarkan pengaturannya tetap berlangsung menurut hukum adat setempat. Mengatur hak ulayat menurut para perancang dan pembentuk UUPA akan berakibat menghambat perkembangan alamiah hak ulayat, yang pada kenyataannya memang cenderung melemah. ${ }^{7}$

Pemikiran tersebut tentu sedikit banyak mempengaruhi pemikiran terkait dengan pengakuan dan pengaturan hak ulayat dalam pembentukan peraturan perundang-undangan, terutama yang terkait dengan tanah dan sumber daya alam. Selain itu, pembentukan peraturan perundang-undangan bidang sumberdaya alam yang masih bersifat pragmatis dan sektoral, juga turut andil mengancam eksistensi hak ulayat MHA. ${ }^{8}$

Hak ulayat sebagai hak yang melekat pada MHA mempunyai daya laku ke dalam dan ke luar. ${ }^{9}$ Hak ulayat mempunyai daya laku ke dalam menunjukkan bagaimana pengaturan dan penggunaan hak ulayat untuk kepentingan anggota MHA. Seorang anggota MHA tanpa diharuskan meminta izin dari tetua adat dapat mengambil hasil hutan, hasil sungai, berburu dan lain sebagainya, asal hasilnya itu diperuntukkan bagi pemenuhan kebutuhan diri sendiri dan keluarganya. ${ }^{10}$ Jika hasil yang diperolehnya itu untuk keperluan perdagangan, maka anggota MHA itu diperlakukan sebagai orang asing dan diharuskan menyerahkan sepersepuluhnya kepada penguasa adat. ${ }^{11}$ Daya laku ke luar dari hak ulayat terlihat dari bagaimana MHA berhubungan dengan orang luar (bukan anggota MHA). Dalam konteks berdaya laku ke luar, orang luar dapat memanfaatkan hak ulayat dengan jalan meminta izin dan membayar recognisi dan/atau retribusi kepada MHA. ${ }^{12}$

Sehubungan dengan uraian di atas, penelitian ini membatasi kajian pada soal bagaimana daya laku ke luar dari hak ulayat. Dalam arti kata, penelitian ini mencermati dan meneliti bagaimana pola hubungan hukum antara MHA dengan pihak luar di dalam pemanfaatan tanah ulayat.

Di dalam penelitian ini, hubungan hukum itu didefinisikan sebagai hubungan yang diatur oleh hukum. ${ }^{13}$ Hubungan hukum itu bisa muncul oleh karena adanya perbuatan hukum yang dilakukan oleh subjek hukum. Menurut Peter Mahmud Marzuki, hubungan hukum bisa saja terjadi di antara sesama subjek hukum dan antara subyek hukum dengan barang. ${ }^{14}$ Dengan demikian, suatu hubungan hukum memberikan hak dan kewajiban yang kalau dilanggar akan berakibat bahwa orang yang melanggar itu dapat dituntut di muka pengadilan. ${ }^{15}$ Atas dasar itu, analisis pola hubungan hukum pemanfaatan tanah ulayat ditinjau dari konsep subyek hukum dan obyek hukum. Setelah itu, dirumuskanlah bagaimana pola hubungan hukum antara subyek hukum dan obyek hukum dalam praktiknya di lapangan. Subyek hukum ${ }^{16}$

\footnotetext{
Periksa Penjelasan Umum II angka (3) Undang-Undang Nomor 5 Tahun 1960 tentang Peraturan Dasar Pokok-Pokok Agraria (Lembaran Negara Republik Indonesia Tahun 1960 Nomor 104; Tambahan Lembaran Negara Nomor 2043).

Boedi Harsono, 2005, Hukum Agraria Indonesia: Sejarah Pembentukan Undang-Undang Pokok Agraria, Isi, dan Pelaksanaannya, Djambatan, Jakarta, hlm. 193.

Kondisi seperti ini dapat dibaca di dalam Maria S.W. Sumardjono, 2005, Kebijakan Pertanahan: antara Regulasi dan Implementasi, Kompas Media Nusantara, Jakarta, hlm. 54-67 dan hlm. 226-232.

Pembahasan secara rinci mengenai hal ini, dapat dibaca di dalam Muhammad Bakri, 2007, Hak Menguasai Tanah oleh Negara: Paradigma Baru untuk Reformasi Agraria, Citra Media, Yogyakarta, hlm. 111-114.

Hal ini juga diakui Boedi Harsono, Op.cit, hlm. 187.

Ibid, hlm. 187.

Maria S.W Sumardjono, 1982, Puspita Serangkum Aneka Masalah Hukum Agraria, Andi Offset, Yogyakarta, hlm. 8.

Seperti dikemukakan Peter Mahmud Marzuki, 2012, Pengantar Ilmu Hukum, Kencana Prenada Media Group, Jakarta, hlm. 216.

Ibid.

Soedjono Dirdjosisworo, 2010, Pengantar Ilmu Hukum, Raja Grafindo Persada, Jakarta, hlm. 131-132.

Subyek hukum adalah pendukung hak yang terdiri dari orang (persoon) dan badan hukum (rechtpersoon).
} 
dalam penelitian ini adalah MHA dan pihak pemanfaatan tanah ulayat. Sedangkan yang menjadi obyek hukumnya ${ }^{17}$ adalah tanah ulayat.

Dalam konteks kekinian, perihal pola hubungan hukum antara MHA dengan pihak luar merupakan isu strategis dalam menyelesaikan sengketa tanah ulayat yang masih marak terjadi seperti di Sumatera Barat. Rumitnya penyelesaian sengketa tanah ulayat terkadang dipicu oleh karena tidak jelasnya hubungan hukum yang terjadi antara MHA dengan pihak luar. Kondisi ini kemudian diperparah dengan banyaknya peraturan perundang-undangan yang bersifat sektoral yang terkadang satu sama lainnya saling menegasikan. Rezim peraturan perundang-undangan yang bersifat sektoral dan saling bertentangan ini membawa konsekuensi harus dilakukannya pilihan hukum dalam membangun dan membina jalinan hubungan hukum antara MHA dengan pihak luar.

Penelitian ini membatasi kajiannya pada pemanfaatan tanah ulayat untuk 4 (empat) sektor sumberdaya alam, yaitu perkebunan, sumberdaya air, pertambangan dan kehutanan. Dengan demikian, permasalahan yang harus ditemukan jawabannya dalam penelitian menjadi 4 (empat) pula, yaitu: Pertama, bagaimana pola hubungan hukum antara MHA dan investor dalam pemanfaatan tanah ulayat untuk usaha perkebunan? Kedua, bagaimana pola hubungan hukum antara MHA dan pihak luar dalam pemanfaatan tanah ulayat untuk usaha pertambangan? Ketiga, bagaimana pola hubungan hukum antara MHA dan pihak luar dalam pemanfaatan tanah ulayat untuk usaha pengelolaan sumberdaya air? dan Keempat, bagaimana pola hubungan hukum antara MHA dan pihak luar dalam pemanfaatan tanah ulayat untuk usaha kehutanan?

\section{B. Metode Penelitian}

Penelitian ini adalah penelitian hukum dengan menggunakan pendekatan yuridis empiris (socio-legal research). Melalui pendekatan sociolegal, penelitian ini menganalisis hubungan hukum dalam pemanfaatan tanah ulayat sebagai fenomena sosial dengan menggunakan perspektif hukum, baik hukum negara maupun hukum adat. Sebagaimana lazimnya penelitian pelaksanaan hukum di masyarakat (sosio-legal research), penelitian ini membutuhkan data, baik data primer yang berasal dari responden maupun data sekunder yang berasal utamanya dari "bahan hukum". Data primer yang diperlukan berupa informasi yang terkait dengan pola hubungan hukum antara MHA dengan pihak luar dalam pemanfaatan tanah ulayat. Berkaitan dengan itu, maka teknik sampling yang digunakan untuk menentukan responden penelitian ini adalah menggunakan teknik purposive sampling. Bahan hukum sebagai sumber utama data sekunder penelitian ini terdiri atas bahan hukum primer (peraturan perundang-undangan yang berlaku terkait dengan tanah ulayat); bahan hukum sekunder (literatur-literatur yang menjelaskan bahan hukum primer), dan bahan hukum tersier (kamus hukum, ensiklopedi, dan lain-lain). Untuk memperoleh data primer dari responden, penelitian ini memakai metode wawancara semi-structured. Dalam teknisnya, pertanyaan-pertanyaan dipersiapkan terlebih dahulu, kemudian satu-persatu diperdalam dengan mengorek keterangan lebih lanjut dari responden, ${ }^{18}$ sedangkan untuk memperoleh data sekunder, dilakukan melalui studi dokumen. Data diperoleh melalui penelusuran isi dokumen dan mengelompokkannya ke dalam konsep-konsep pokok yang terdapat dalam rumusan masalah. Penelitian ini menggunakan teknik atau metode pengolahan dan analisis data kualitatif. Uraian kegiatan pengolahan dan analisisnya meliputi: (1) reduksi data; (2) penyederhanaan dan penyajian data; dan (3) verifikasi hasil penelitian serta penarikan kesimpulan. 
C. Hasil Penelitian dan Pembahasan

1. Pola Hubungan Hukum dalam Pemanfaatan Tanah Ulayat untuk Usaha Perkebunan

Pembangunan perkebunan di Sumatera Barat pada umumnya dilaksanakan dengan cara pemberian Hak Guna Usaha (HGU) ${ }^{19}$ kepada pengusaha. Konsekuensinya, hubungan hukum antara MHA sebagai pemilik dan/atau penguasa tanah ulayat dan pengusaha tidak merupakan hubungan langsung. HGU lahir berdasarkan pemberian hak oleh negara melalui pejabat, bukan berdasarkan perbuatan hukum (perjanjian) antara masyarakat hukum adat dengan pengusaha.

Penelitian ini melihat pola hubungan hukum pemanfaatan tanah ulayat untuk usaha perkebunan di salah satu nagari di Kabupaten Agam, yaitu Nagari Bawan, Kecamatan Ampek Nagari. Nagari ini merupakan salah satu nagari yang banyak mengalami konflik dan sengketa pemanfaatan tanah ulayat di bidang perkebunan. Sebetulnya, dalam praktik di Sumatera Barat, termasuk di lokasi penelitian, hubungan hukum dalam pemanfaatan tanah ulayat untuk usaha perkebunan terjadi dalam tiga tahapan, yaitu: (1) penyerahan tanah ulayat oleh MHA kepada bupati sebagai kepala daerah; (2) penyerahan tanah ulayat oleh kepala daerah kepada pengusaha; dan (3) pemberian hak guna usaha oleh negara kepada pengusaha. ${ }^{20}$

Dapat dikatakan bahwa sebagian besar proses pembangunan perkebunan terutama sawit di Sumatera Barat berawal dari adanya penyerahan tanah ulayat oleh masyarakat hukum adat kepada kepala daerah (bupati). ${ }^{21}$ Kepala daerah (bupati) merupakan pihak yang aktif dalam mewujudkan kegiatan usaha perkebunan. Setelah tanah ulayat diserahkan oleh MHA kepada bupati, baik yang termasuk kawasan hutan maupun tidak, baru dilakukan "penyerahan" tanah tersebut oleh bupati kepada perusahaan perkebunan. Namun, bupati sebetulnya tidak menyerahkan tanah tersebut kepada perusahaan, melainkan hanya mengabulkan permohonan penyediaan lahan kebun yang diajukan oleh perusahaan kepada bupati.

Setelah proses penyerahan tanah ulayat oleh bupati kepada pengusaha tuntas dilaksanakan, tanah ulayat tersebut selanjutnya diubah statusnya menjadi tanah negara. Setelah itu, barulah tanah tersebut dilekati dengan $\mathrm{HGU}$ atas nama perusahaan yang akan melakukan kegiatan usaha perkebunan. Pertanyaannya adalah: (a) bagaimana kewajiban pengusaha terhadap MHA pemilik ulayat terkait dengan pemberian HGU kepada pengusaha?; (b) bagaimana akibat hukum bagi pengusaha yang tidak memenuhi kewajibannya kepada MHA?; dan (c) bagaimana status tanah ulayat setelah masa berlaku HGU berakhir? Jawaban atas pertanyaanpertanyaan ini tentu tidak mudah dan bahkan mungkin tidak dapat dijawab secara tuntas, karena hubungan hukum antara MHA dan pengusaha pemegang HGU untuk perkebunan tidak lagi nyata. Hubungan hukum antara MHA dan pengusaha hanya relevan dibicarakan dalam proses pelepasan hak tanah ulayat untuk dijadikan HGU perkebunan. Setelah HGU diberikan oleh negara maka hubungan hukumnya beralih menjadi hubungan hukum dalam lapangan hukum publik (administrasi negara) antara pengusaha dan pemerintah. Hal ini ditandai dengan dicantumkannya hak dan kewajiban dari pengusaha sebagai pemegang HGU di dalam surat keputusan pemberian HGU yang bersangkutan.

Persoalannya adalah tidak dimungkinkannya

19 Hak Guna Usaha (HGU) merupakan hak mengusahakan tanah yang dikuasai langsung oleh negara (tanah negara) untuk usaha pertanian, peternakan, dan perikanan dalam jangka waktu tertentu.

20 Terungkap pula dalam wawancara dan diksusi terbatas dengan A. Dtk Rajo Marajo dkk., Ninik Mamak Nagari Bawan, 28 September 2013.

21 Seperti perkebunan sawit yang terdapat di Kabupaten Agam, Pasaman Barat, Pasaman, Pesisir Selatan, dan Dharmasraya. Untuk Kabupaten Agam, baca Afni Gusni Susanti, 2013, Pelaksanaan Perjanjian Pembangunan dan Pengelolaan Perkebunan Kelapa Sawit dengan Pola Kemitraan/Inti Plasma antara Ninik Mamak Bawan dengan PT AMP Plantation di Tanah Ulayat Bawan Kecamatan Ampek Nagari Kabupaten Agama, Tesis, Program Pascasarjana Fakultas Hukum Universitas Andalas, Padang, hlm. 99-113. Untuk di Kabupaten Pesisir Selatan, baca di antaranya, Novrial, 2012, Pemanfaatan Tanah Ulayat untuk Perkebunan di Nagari Tapan Kabupaten Pesisir Selatan, Tesis, Program Magister Kenotariatan Fakultas Hukum Universitas Andalas, Padang, hlm. 72-90. Untuk di Pasaman Barat, baca pula Hanifzar, 2010, Penyelesaian Sengketa Tanah Ulayat di Kabupaten Pasaman Barat (Studi Sengketa Tanah Perkebunan PT Gersindi Minang Plantation), Tesis, Program Pascasarjana Program Sudi Ilmu Hukum Universitas Andalas, Padang, hlm. 86-97. 
secara normatif pemberian HGU di atas tanah ulayat. HGU hanya bisa diberikan di atas tanah negara. Oleh karena itu, ketika tanah ulayat dibutuhkan untuk keperluan HGU, maka tanah ulayat harus dilepaskan dan diubah statusnya menjadi tanah negara. Ketentuan seperti ini tentu saja merugikan MHA, karena secara yuridis tanah ulayat mereka telah berubah status menjadi tanah negara. Dengan demikian, tanah ulayat MHA menjadi punah setelah melalui proses pemberian HGU kepada pengusaha. Walaupun UU No. 18 Tahun 2004 tentang Perkebunan mengakui keberadaan hak ulayat MHA, namun pengakuan itu hanya ditempatkan pada posisi sebagai dasar negosiasi pemanfaatan tanah ulayat yang kemudian diiringi dengan penyerahan tanah ulayat tersebut kepada pihak yang memerlukan. ${ }^{22}$

\section{Pola Hubungan Hukum dalam Peman- faatan Tanah Ulayat untuk Usaha Pengelolaan Sumberdaya Air}

Studi mengenai pola hubungan hukum antara MHA dan pihak luar di bidang pengelolaan sumberdaya air dilakukan di Nagari Sungai Kamuyang Kabupaten Limapuluh Kota. Sungai Kamuyang dipilih sebagai lokasi penelitian atas dasar pertimbangan bahwa pemanfaatan sumberdaya air di nagari ini merupakan salah satu contoh kasus yang baik (best practice) dalam pemanfaatan tanah ulayat MHA. Sumber mata air Batang Tabit yang menjadi obyek penelitian ini adalah ulayat Nagari Sungai Kamuyang. Pengelolaannya diserahkan kepada Pemerintah Nagari atau Kerapatan Adat Nagari (KAN) yang menjadi representasi dari MHA Nagari. Walaupun diatur dan dikelola oleh Pemerintah Nagari atau KAN, hak MHA Nagari terhadap ulayat nagari tersebut tidak berpindah kepada Pemerintah Nagari atau KAN.

Subyek hukum ulayat nagari adalah MHA Nagari Sungai Kamuyang. ${ }^{23}$ Dalam praktiknya, hubungan hukum dengan pihak lain tidak dilaksanakan secara bersama-sama oleh MHA
Nagari, tetapi dilaksanakan atau diwakili oleh Pemerintah Nagari atau KAN sebagai representasi masyarakat. Pada kurun waktu 1975-1979, pengaturan pemanfaatan ulayat nagari dilakukan oleh Pemerintah Nagari. Untuk itu, hubungan hukum dalam pemanfaatan air Batang Tabit terjadi antara Pemerintah Kota Payakumbuh (Perusahaan Daerah Air Minum/PDAM Kota Payakumbuh) dan Pemerintah Nagari. Namun, sejak diterapkannya sistem pemerintahan desa berdasarkan UU No. 5 Tahun 1979, MHA Nagari Sungai Kamuyang tidak lagi diwakili oleh Pemerintah Nagari dalam mengadakan perbuatan hukum dengan Pemerintah Kota Payakumbuh, tetapi diambil alih oleh KAN. Kedudukan KAN dalam hal ini sesuai dengan Perda Provinsi Sumatera Barat No. 13 Tahun 1983. Pada masa ini, ada pemisahan antara urusan pemerintahan dengan urusan adat.

Seiring dengan penerapan kembali sistem pemerintahan nagari pada 2000, pengaturan pemanfaatan sumber air Batang Tabit dikembalikan pengelolaannya kepada Pemerintah Nagari. Dengan demikian, perbuatan hukum dalam pemanfaatan sumber mata air Batang Tabit kembali diwakili oleh Pemerintah Nagari Sungai Kamuyang. Secara normatif, sumbermataair Batang Tabit sebagai obyek hubungan hukum antara Pemerintah Nagari Sungai Kamuyang dengan PDAM Kota Payakumbuh diatur oleh UU No. 7 Tahun 2004 tentang Sumberdaya Air. Menurut Pasal 6 ayat (2) UU No. 7 Tahun 2004, penguasaan sumber daya air diselenggarakan oleh Pemerintah dan/atau Pemerintah Daerah dengan tetap mengakui hak ulayat MHA setempat dan hak yang serupa dengan itu, sepanjang tidak bertentangan dengan kepentingan nasional dan peraturan perundang-undangan. Lebih lanjut, Pasal 6 ayat (3) UU No. 7 Tahun 2004 juga memberikan penekanan bahwa hak ulayat MHA atas sumberdaya air tetap diakui sepanjang kenyataannya masih ada dan telah dikukuhkan dengan Peraturan Daerah

Seperti ketentuan Pasal 9 ayat (2) Undang-Undang Nomor 18 Tahun 2004 tentang Perkebunan (Lembaran Negara Republik Indonesia Tahun 2004 Nomor 85, Tambahan Lembaran Negara Republik Indonesia Nomor 4411).

23 Sejalan dengan Boedi Harsono, Op.cit., hlm. 183. 
setempat. Berdasarkan Pasal 6 ayat (2) dan ayat (3) tersebut, dapat diperoleh kesimpulan sebagai berikut: Pertama, penyelenggaraan pemanfaatan sumberdaya air dilakukan oleh Pemerintah dan/atau Pemerintah Daerah; dan Kedua, hak ulayat MHA akan diakui keberadaannya setelah dikukuhkan oleh Peraturan Daerah.

Dengan adanya kewenangan itu, maka Pemerintah dan/atau Pemerintah Daerah dapat memberikan hak guna air, baik dalam bentuk hak guna pakai air dan hak guna usaha air. Kewenangan tersebut sama sekali tidak dimiliki oleh pemerintah desa maupun MHA. Dalam praktik, hubungan hukum yang terjadi sama sekali tidak mengacu kepada UU No. 7 Tahun 2004. PDAM Kota Payakumbuh memanfaatkan sumber air Batang Tabit tidak berdasarkan adanya hak guna usaha air. ${ }^{24}$ PDAM Kota Payakumbuh memanfaatkan sumber mata air Batang Tabit atas dasar adanya kesepakatan pada 1975. Dengan demikian, hubungan hukum ini telah berjalan lama, yaitu sejak tahun 1975. Hubungan hukum tersebut tidak dituangkan ke dalam bentuk perjanjian yang dibuat khusus untuk itu, melainkan karena adanya kesepakatan para pihak berdasarkan korespondensi surat menyurat di antara mereka.

Kronologisnya, hubungan hukum antara Nagari Sungai Kamuyang dengan PDAM diawali dengan adanya pengajuan permohonan pemanfaatan sumber air dari Pemerintah Kota Payakumbuh kepada Pemerintah Nagari melalui Pemerintah Kabupaten Limapuluh Kota. Menyikapi hal ini, Pemerintah Nagari Sungai Kamuyang melakukan rapat bersama dengan pemuka masyarakat. Nagari Sungai Kamuyang menyatakan bersedia memberikan air bersih untuk Pemerintah Kota Payakumbuh (PDAM Kota Payakumbuh) dengan beberapa persyaratan sebagaimana tertuang dalam surat Wali Nagari Sungai Kamuyang tertanggal 22
Desember 1974. Pemerintah Kota Payakumbuh (PDAM Kota Payakumbuh) dengan melalui perantara Pemerintah Kabupaten Limapuluh Kota menyatakan bersedia memenuhi persyaratan yang diajukan, melalui Surat Bupati Limapuluh Kota No. 547/V/14-75 tertanggal 27 Januari 1975.

Ditinjau dari segi hukum pembuktian, korespondensi antara Pemerintah Nagari Sungai Kamuyang dengan Pemerintah Kabupaten Limapuluh Kota terkategori sebagai surat yang bukan akta. Hal ini disebabkan karena surat menyurat antara Pemerintah Nagari Sungai Kamuyang dengan Pemerintah Kabupaten Limapuluh Kota tidak dimaksudkan sebagai alat pembuktian di kemudian hari. ${ }^{25}$ Kekuatan pembuktian dari surat yang bukan akta tidaklah sekuat dari kekuatan pembuktian surat yang berupa akta. Menurut Sudikno Mertokusumo, kekuatan pembuktian dari surat-surat yang bukan akta diserahkan kepada pertimbangan hakim. ${ }^{26}$

Setelah kembali hidup bernagari, ada beberapa kesepakatan yang dinegosiasi ulang. Dalam hal ini, Pemerintah Nagari Sungai Kamuyang meminta pada PDAM Kota Payakumbuh untuk menaikkan harga tarif dasar air dari $\mathrm{Rp} 200 / \mathrm{m}^{3}$ (dua ratus rupiah per meter kubik) menjadi 400/ $\mathrm{m}^{3}$ (empat ratus rupiah per meter kubik). Selain itu, pembayaran kontribusi pemanfaatan sumber mata air Batang Tabit diminta dibayarkan paling lambat pada tanggal 15 setiap bulannya yang disetor langsung ke nomor rekening Pemerintah Nagari Sungai Kamuyang.

Permintaan dari Pemerintah Nagari Sungai Kamuyang dikabulkan oleh PDAM Kota Payakumbuh. Kesepakatan ini tidak dituangkan ke dalam surat perjanjian, namun lahir atas dasar adanya korespondensi surat menyurat di antara mereka. Selain melalui korespondensi, peninjauan hubungan hukum dalam pemanfaatan sumber mata air Batang Tabit juga dilakukan berdasarkan hasil musyawarah mufakat yang dituangkan ke dalam

24 Pasal 8 ayat (4) Peraturan Pemerintah Nomor 16 Tahun 2005 tentang Pengembangan Sistem Penyediaan Air Minum (Lembaran Negara Republik Indonesia Tahun 2005 Nomor 33, Tambahan Lembaran Negara Republik Indonesia Nomor 4490) menyebutkan bahwa penggunaan air baku untuk keperluan pengusahaan air minum wajib berdasarkan izin hak guna usaha air sesuai peraturan perundang-undangan.

25 Akta adalah surat sebagai alat bukti yang diberi tanda tangan, yang memuat peristiwa yang menjadi dasar suatu hak atau perikatan, yang dibuat sejak semula dengan sengaja untuk pembuktian.

26 Sudikno Mertokusumo, 2002, Hukum Acara Perdata Indonesia, Liberty, Yogyakarta, hlm. 157. 
notulen rapat dan berita acara yang ditandatangani oleh para pihak. Salah satu hasil kesepakatan penting yang diperoleh dari musyawarah tersebut adalah PDAM membayar kontribusi sebesar 10\% dari harga tarif dasar air dikalikan dengan jumlah air terjual di mana kontribusi tersebut selanjutnya dibagi 5\% untuk Pemerintah Nagari Sungai Kamuyang dan 5\% untuk Pemerintah Kabupaten Limapuluh Kota.

Dalam hal ini dapat diambil pelajaran, bahwa walaupun hubungan hukum antara Nagari Sungai Kamuyang dengan PDAM Kota Payakumbuh tidak jelas dari awal, namun dengan adanya pengakuan terhadap keberadaan ulayat nagari, ketidakjelasan hubungan hukum itu tidaklah menjadi suatu kendala. Dengan demikian, pengakuan terhadap hak ulayat merupakan faktor strategis di dalam membina dan melanjutkan hubungan hukum di dalam pemanfaatan tanah ulayat. Pada kasus Nagari Sungai Kamuyang, pemanfaatan ulayat nagari ternyata memberikan keuntungan kepada semua pihak, tidak hanya menguntungkan masyarakat, namun juga menguntungkan Pemerintah Daerah sebagai "instansi atasan" dari Pemerintah Nagari.

3. Pola Hubungan Hukum dalam Pemanfaatan Tanah Ulayat untuk Usaha Pertambangan

Untuk melihat pola hubungan hukum dalam pemanfaatan tanah ulayat untuk usaha di bidang pertambangan, penelitian ini difokuskan pada Kabupaten Solok sebagai salah satu daerah yang memiliki potensi tambang yang besar. Nagari lokasi penelitian ini adalah Nagari Aie Dingin, Kecamatan Lembah Gumanti. Aie Dingin memiliki kekayaan alam berupa bahan galian atau sumberdaya tambang berupa mineral baik logam maupun bukan logam (galian C). Kandungan mineral logam yang mendominasi di nagari ini adalah bijih besi, sedangkan mineral bukan logam yang terbanyak adalah pasir. Dua jenis bahan tambang atau mineral ini bahkan menjadi primadona bagi perekonomian masyarakat setempat saat ini. Kegiatan pertambangan di Nagari Aie Dingin pada umumnya terdiri atas dua bentuk pertambangan yaitu tambang biji besi yang dilakukan oleh perusahaan dan mempunyai izin, dan tambang pasir yang dilakukan pada umumnya oleh rakyat setempat. ${ }^{27}$

Karena Izin Usaha Pertambangan (IUP) tidak meliputi hak atas tanah, maka setiap orang yang akan melaksanakan penambangan di wilayah pertambangan harus memastikan terlebih dahulu status hukum tanah yang digunakan. Menurut Salim disinilah letak hubungan yang erat antara Hukum Pertambangan dan Hukum Agraria. ${ }^{28}$ Berikut ini dikemukakan salah satu contoh hubungan hukum antara MHA dan pengusaha dalam pemanfaatan tanah ulayat untuk pelaksanaan IUP di Nagari Aie Dingin, Kabupaten Solok. Pemanfaatan tanah ulayat yang akan dikemukakan ini adalah untuk wilayah IUP Eksplorasi dari CV Minang Pangeran Resources. Pada akhir November 2011 CV Minang Pangeran Resources ini berubah menjadi perusahaan berbadan hukum berbentuk Perseroan Terbatas (PT), dengan nama PT Minang Pangeran.

Pada pertengahan Tahun 2011 (7 Juli 2011) PT Minang Pengeran, saat itu bernama CV Minang Pangeran Resources, memperoleh IUP Eksplorasi dari Bupati Solok, melalui Surat Keputusan No. 540-306-2011. ${ }^{29}$ Izin ini merupakan perubahan nama sekaligus perpanjangan dari Izin Kuasa Pertambangan Eksplorasi yang telah dipegang oleh perusahaan ini sebelumnya. Perubahan nama izin ini juga dimaksud untuk menyesuaikan istilah dengan yang disebutkan di dalam UU No. 4 Tahun 2009 tentang Pertambangan Mineral dan Batubara (UU Minerba). Di samping permohonan dari yang bersangkutan, IUP ini juga dikeluarkan berdasarkan rekomendasi dari Walinagari Aie Dingin, yang

\footnotetext{
Seperti terungkap dalam diskusi fokus (FGD) terbatas dengan Fauzi Izwari dan kawan-kawan, Tokoh Masyarakat dan Pemuda Nagari Aie Dingin, di lokasi pada 23 Agustus 2013.

28 Lebih jauh baca Salim H.S., 2012, Hukum Pertambangan di Indonesia, Rajawali Press, Jakarta, hlm. 25-26. Lihat juga Sudikno Mertokusumo, 2002, Hukum Acara Perdata Indonesia, Liberty, Yogyakarta, hlm. 157.

29 Surat Keputusan Bupati Solok tentang Nomor 540-306-2011 tentang Izin Usaha Pertambangan Eksplorasi.
} 
diketahui Camat setempat. Komoditas tambang yang diusahakan oleh perusahaan ini adalah bijih besi (mineral logam), dengan luas wilayah $74 \mathrm{Ha}$.

IUPEksplorasi tersebut berlaku satu tahun dan berakhir pada 6 Juli 2012. Untuk itu, jika prosesnya berjalan lancar dan segala persyaratan terpenuhi, maka IUP Eksplorasi itu akan ditingkatkan menjadi IUP Eksploitasi. Salah satu persyaratan IUP Eksploitasi adalah penyelesaian permasalahan tanah dengan seluruh pemilik tanah yang ada di lokasi izin. Untuk menyambut itulah, pada 2 Maret 2012 PT Minang Pangeran mengadakan perjanjian dengan para pemilik tanah (penguasa ulayat). Perjanjian ini dibuat dengan memakai akta notaris, Muhammad Ishaq, S.H. di Padang. Perjanjian ini melahirkan hubungan hukum antara pengusaha dan pemegang ulayat yang berisi hak dan kewajiban sebagai berikut:

a. Para pemegang tanah ulayat sebagai pihak pertama bersedia menyerahkan dan memberi izin kepada pengusaha sebagai pihak kedua untuk melakukan kegiatan produksi pertambangan dan penjualan hasil tambang bijih besi, termasuk mengurus semua surat-surat perizinan dan dokumen-dokumen lain terkait dengan pelaksanaan izin.

b. Pihak pertama menjamin pihak kedua untuk dapat menjalankan usahanya dengan tenang dan lancar tanpa adanya gangguan dari pihak manapun.

c. Pihak pertama menjamin pihak kedua tidak akan ada tuntutan dalam bentuk apapun juga dari pihak ketiga lainnya yang merasa ikut memiliki hak atas tanah areal izin yang dapat mengganggu kegiatan operasional.

d. Pihak kedua wajib menyampaikan rencana kerja kepada pihak pertama.

e. Pihak kedua wajib mengutamakan masyarakat setempat sebagai karyawan sesuai dengan kemampuan yang ada.

f. Pihak kedua juga wajib membayar fee kepada pihak pertama sesuai kesepakatan, yaitu Rp7.500/MT (tujuh ribu lima ratus rupiah per matric ton) kepada semua pemilik lahan dengan hak sama di antara mereka. g. Pihak kedua wajib mengganti tanaman tumbuh produktif yang ada di atas tanah lokasi izin kepada pihak pertama.

h. Pihak kedua juga wajib membantu pembiayaan pendidikan masyarakat setempat yang berprestasi dalam bentuk beasiswa.

i. Pihak kedua wajib menjaga ketertiban dan keamanan di lokasi usaha serta menghormati adat istiadat setempat.

j. Pihak kedua wajib menyerahkan kembali tanah ulayat pihak pertama setelah habis masa berlaku izin usaha.

Pola hubungan hukum dalam pemanfaatan tanah ulayat untuk usaha pertambangan di atas terjadi karena menurut hukum pertambangan bahwa IUP hanya berisi kewenangan untuk mengambil bahan tambangnya saja, tidak meliputi hak atas tanah. Untuk itu perumus UU Minerba merasa perlu membuat suatu bab di dalam batang tubuhnya UU ini mengatur tentang penggunaan tanah. Ketentuan ini terdapat pada Bab XVIII UU No. 4 Tahun 2009 dengan judul Penggunaan Tanah Untuk Kegiatan Usaha Pertambangan, terdiri atas lima pasal, yaitu Pasal 134-138. Pasal 134 sebagai ketentuan dasar tentang penggunaan tanah untuk usaha pertambangan menegaskan ulang, bahwa hak atas Wilayah Izin Usaha Pertambangan (WIUP), Wilayah Pertambangan Rakyat(WPR), atau Wilayah Izin Usaha Pertambangan Khusus (WIUPK) tidak meliputi hak atas tanah permukaan bumi. Berkaitan dengan itu, kegiatan usaha pertambangan tidak dapat dilaksanakan pada tempat yang dilarang untuk melakukan kegiatan usaha pertambangan sesuai dengan hukum pertanahan.

Oleh karena itu, pemegang IUP Eksplorasi atau IUPK Eksplorasi hanya dapat melaksanakan kegiatannya setelah mendapat persetujuan dari pemegang hak atas tanah (Pasal 135 UU Minerba). Tidak hanya itu, jika IUP Eksplorasi itu ditingkatkan menjadi IUP Eksploitasi atau operasi produksi wajib menyelesaikan hak atas tanah dengan pemegang haknya. Hal inilah yang ditegaskan oleh Pasal 136 UU Minerba, bahwa pemegang IUP atau IUPK sebelum melakukan kegiatan operasi produksi wajib menyelesaikan hak atas tanah dengan pemegang 
hak sesuai dengan ketentuan peraturan perundangundangan.

Ketentuan ini dikunci dengan ketentuan Pasal 137, bahwa pemegang IUP atau IUPK yang telah melaksanakan penyelesaian terhadap bidangbidang tanah dapat diberikan hak atas tanah sesuai dengan ketentuan peraturan perundang-undangan. Pengurusan hak atas tanah tersebut dilakukan karena sekali lagi ditegaskan bahwa hak atas IUP, IPR, atau IUPK bukan merupakan pemilikan hak atas tanah (Pasal 138 UU Minerba). Dari pembahasan di atas dapat dikemukakan beberapa catatan sebagai berikut.

a. Hubungan hukum antara pengusaha dan pemilik ulayat dalam pemanfaatan tanah ulayat untuk usaha pertambangan lebih terbuka. Hal ini memungkinkan kepada kedua pihak untuk menyepakati hal-hal sesuai dengan keinginan mereka. Pemberian IUP tidak mensyaratkan pelepasan hak atas tanah ulayat dan pelaksanaan izinnya juga tidak mengharuskan adanya hak atas tanah tertentu. Pengusaha pemegang izin usaha pertambangan juga tidak terlalu berkepentingan dengan adanya hak atas tanah tertentu. Yang penting bagi mereka adalah kepastian untuk menjalankan izin usahanya. Pengusaha di bidang pertambangan juga tidak membutuhkan sertipikat hak atas tanah untuk dijadikan sebagai agunan kredit perbankan. Secara faktual pada umumnya pengusaha pertambangan tidak membutuhkan hak tanggungan atas tanahnya.

b. Hal ini berbeda dengan usaha perkebunan. Kegiatan perkebunan berbasis pada tanah dan hak atas tanah. Pada umumnya pengusaha kebun menjadikan tanah dan hak atas tanah sebagai obyek penting dalam proses usahanya. Di samping untuk kepastian berusaha di atas tanah, hak atas tanahnya juga dijadikan sebagai obyek hak tanggungan dalam memperoleh kredit perbankan. Kalau saja pengusaha perkebunan tidak tergantung kepada bantuan kredit bank dengan menjadikan hak atas tanahnya sebagai obyek hak tanggungan maka pola hubungan hukum dalam pemanfaatan tanah ulayat untuk perkebunan akan lebih dinamis.

c. Pelaksanaan usaha pertambangan berdasarkan IUP yang telah diberikan tidak disertai dengan pemberian hak atas tanah kepada pengusaha. Sehingga pola hubungan hukum antara pengusaha dan pemilik ulayat dapat dipertahankan sampai berakhirnya masa IUP.

\section{Pola Hubungan Hukum dalam Peman- faatan Tanah Ulayat untuk Usaha Kehu- tanan}

Kegiatan penelitian ini melihat pola hubungan hukum dalam pemanfaatan tanah ulayat untuk usaha kehutanan di Kabupaten Solok Selatan, salah satu kabupaten yang memiliki potensi sumberdaya hutan relatif besar. Di samping itu, kabupaten ini juga telah mempunyai pengalaman sebagai lokasi kegiatan usaha kehutanan lebih lama. Pemanfaatan tanah ulayat untuk usaha kehutanan di lokasi ini yang paling menonjol adalah pemanfaatan ulayat untuk wilayah konsesi PT Andalas Merapi Timber (PT AMT). PT AMT menjalankan usahanya sebagai pemegang izin usaha pemanfaatan hasil hutan kayu (IUPHHK) berdasarkan Surat Keputusan Menteri Kehutanan No. 82/Kpts-II/2000, 22 Desember $2000 .{ }^{30}$ Keputusan ini sebetulnya merupakan dasar hukum bagi perpanjangan Izin Usaha Pemanfaatan Hasil Hutan Kayu (IUPHHK) bagi PT AMT, yang sudah diberikan sebelumnya dengan nama Hak Pengusahaan Hutan (HPH). Saat ini, luas wilayah IUPHHK yang dimiliki oleh PT AMT adalah 28.840 Ha. Lokasi ini merupakan wilayah yang berstatus sebagai tanah ulayat dari beberapa nagari yang terdapat di empat kecamatan, yaitu Kecamatan Sungai Pagu, Kecamatan Sangir, Kecamatan Koto Parik Gadang Diateh (KPGD), Kecamatan Sangir Jujuan dan Kecamatan Sangir. 
Pada saat pemberian dan/atau perpanjangan IUPHHK, wilayah seluas $28.840 \mathrm{Ha}$ itu meliputi tanah atau hutan ulayat dari 9 (sembilan) nagari yaitu: (1) Nagari Pakan Rabaa; (2) Nagari Pasie Talang; (3) Nagari Koto Baru; (4) Nagari Alam Pauh Duo; (5) Nagari Lubuk Gadang; (6) Nagari Lubuk Malako; (7) Nagari Bidar Alam; (8) Nagari Abai; dan (9) Nagari Lubuk Ulang Aliang.

Jika proses pemberian dan/atau perpanjangan IUPHHK ini mengakui keberadaan tanah ulayat MHA setempat tentu PT AMT harus melakukan perbuatan hukum atau perjanjian dengan sembilan nagari ini. Dalam hal ini dapat dilihat bahwa pola hubungan hukum antara pengusaha dan MHA dalam pemanfaatan tanah ulayat tidak jelas, sehingga mudah memicu konflik dan bahkan sengketa. Apalagi sekarang sembilan nagari itu sudah dimekarkan menjadi 21 (dua puluh satu) nagari, tentu pola hubungan hukumnya semakin rumit. ${ }^{31} \mathrm{PT}$ Andalas Merapi Timber (AMT) bukanlah pemain baru dalam bidang usaha kehutanan di Sumatera Barat. Perusahaan ini telah berdiri sejak tanggal 26 Desember 1978. PT AMT mendapatkan IUPHHK berdasarkan Forest Agreement (FA) dari pemerintah dengan Surat Keputusan No. FA/N/024/IV/1980, tanggal 21 April 1980, dan dengan Surat Keputusan Menteri Pertanian No. 624/Kpts/Um/1980, tanggal 26 Agustus $1980 .{ }^{32}$ Luas kawasan usaha kehutanan PT AMT pada saat itu adalah 118.200 Ha. Izin tersebut berakhir pada tanggal 28 Agustus 2000.

Berkaitan dengan pola hubungan hukum dalam pemanfaatan tanah ulayat, sejak PT AMT menjalan usahanya di Solok Selatan berdasarkan Surat Keputusan Menhut No. 82/Kpts-II/2000 ternyata telah menimbulkan sengketa dengan MHA setempat. Misalnya, sengketa kehutanan antara MHA Alam Surambi Sungai Pagu dengan PT AMT terus berlanjut, dan mencapai puncaknya pada 2011. Hal ini ditandai dengan adanya surat protes, tanggal 27 Juli 2011, dari masyarakat setempat kepada PT AMT yang berisi penolakan terhadap keberadaan PT AMT di ulayat mereka. Penolakan masyarakat terhadap keberadaan PT AMT di dalam kawasan hutan ulayat mereka didasarkan pada alasan antara lain: ${ }^{33}$

a. Masyarakat hukum adat setempat tidak diberitahu atau tidak dilibatkan dalam proses perpanjangan IUPHHK PT AMT pada Tahun 2000, tidak dilakukannya musyawarah sebelum perpanjangan izin tersebut diberikan kepada PT AMT.

b. Kegiatan ini telah merusak infrastruktur pembangunan terutama jalan, sementara itu imbalan (siliah jariah dan bungo kayu) yang diterima masyarakat hukum adat melalui Nagari yang dibayarkan PT AMT setiap satu tahun tidak setimpal dengan nilai kayu yang diambil. ${ }^{34}$

c. Kecuali membayar imbalan, PT AMT juga diminta melaporkan hasil atau produksi kayunya setiap tahun kepada nagari-nagari setempat, tetapi realisasinya PT AMT tidak transparan.

d. Masyarakat juga mengetahui terjadinya beberapa pelanggaran yang dilakukan PT AMT, seperti tidak dilaksanakannya pola Tebang Pilih Tanam Kembali (TPTK); penanaman kembali hanya dilakukan beberapa pohon saja dan itu hanya di sekitar Base Camp PT AMT; pelanggaran terhadap larangan penebangan kayu

31 Selain di Kabupaten Solok Selatan, fenomena pemekaran nagari seperti ini telah jamak terjadi di kabupaten lain di Sumatera Barat yaitu Kabupaten Pesisir Selatan, Dharmasraya, Sijunjung, Pasaman Barat, dan lain-lain.

32 Surat Keputusan Nomor FA/N/024/IV/1980, tanggal 21 April 1980 dan Surat Keputusan Menteri Pertanian Nomor 624/Kpts/Um/1980, tanggal 26 Agustus 1980.

33 Terungkap dalam wawancara dengan beberapa tokoh adat dan tokoh masyarakat setempat, khususnya di Nagari Pakan Rabaa, pada 24 Agustus 2013, yaitu E. Dtk. Rajo Bagampo (Sekretaris KAN), A.S. Dtk. Rajo Katik (Ketua KAN Periode 2009-2013), Syafrudin Malik (Walinagari 2001-2007), dan Novri (Pemuda). Kasus ini bahkan sudah menjadi perhatian masyarakat luas, bandingkan dengan informasi serupa melalui internet, KPP-KASRI, "Konflik Tenurial antara Masyarakat dan Alam", http://kkpkasri.blogspot.com/2011/10/konflik-tenurialantara-masyarakat-alam.html, diakses 5 November 2013.

34 Berdasarkan wawancara dengan A.S. Dtk Rajo Katik, Mantan Ketua KAN Pakan Rabaa, 24 Oktober 2013 konvensasi yang diberikan kepada masing-masing adalah Rp 27 juta. Jumlah itu diperuntukkan kepada 9 (sembilan) nagari induknya, dan setelah terjadi pemekaran maka dana tersebut dibagi berimbang di antara nagari hasil pemekaran. Misalnya pada Nagari Pakan Rabaa, karena nagari ini dimekarkan menjadi 4 (empat) nagari maka Rp 27 juta dibagi empat nagari. Jadi masing-masing nagari memperoleh dana kurang dari Rp 7 Juta. 
di kemiringan 45 derajat; tidak melaksanakan kewajiban Corporate Social Responsibility (CSR); penebangan tidak sesuai dengan Rencana Kerja Tahunan (RKT), terjadi penebangan tanpa adanya peruntukan selanjutnya.

Sebagai pengusaha di bidang kehutanan PT AMT sebetulnya tidak mempersoalkan status tanah hutan tempat mereka berusaha. Mereka menyadari bahwa perusahaan tidaklah sebagai pemilik atas tanahnya, melainkan hanya hak pemanfaatan hasil hutannya saja. ${ }^{35}$ Dari uraian di atas terlihat bahwa pola hubungan hukum dalam pemanfaatan tanah ulayat untuk usaha kehutanan tidak terjadi sebagaimana mestinya menurut hukum yang berlaku. Pengakuan konstitusi terhadap keberadaan MHA dan hak ulayatnya belum bisa diwujudkan dalam pemberian izin usaha pemanfaatan hasil hutan. Kesepakatan yang ditempuh pengusaha dengan masyarakat hukum adat dalam menjalankan usahanya hanya sekedar upaya pendekatan saja agar kegiatan usahanya tetap bisa berjalan. Pengusaha merasa berbagai bentuk pendekatan dengan masyarakat termasuk pemberian ganti kerugian atau kompensasi kepada masyarakat terkesan hanya sebagai bentuk kebaikan hati saja dari pengusaha.

Izin usaha kehutanan memang tidak mensyaratkan adanya pelepasan hak tanah ulayat. Pemberian IUPHHK tidak memerlukan adanya hak atas tanah, walaupun kegiatan ini dilakukan di atas tanah yang sangat luas. Dengan demikian, pemberian IUPHHK dapat diberikan langsung oleh pemerintah atau Menteri Kehutanan atas rekomendasi dari Pemerintah Daerah sesuai dengan kewenangannya masing-masing. Dalam hal ini tidak ada hubungan hukum antara pemilik ulayat dengan pengusaha. UU No. 41 Tahun 1999 tentang Kehutanan tidak memberikan pengertian yuridis terhadap IUPHHK ini. Pengertian IUPHHK dapat ditemukan di dalam PP No. 6 Tahun 2007 tentang
Tata Hutan dan Penyusunan Rencana Pengelolaan Hutan, Serta Pemanfaatan Hutan. Pasal 1 angka 13 PP No. 6 Tahun 2007 mengemukakan bahwa IUPHHK adalah izin usaha yang diberikan untuk memanfaatkan hasil hutan berupa kayu dalam hutan alam pada hutan produksi melalui kegiatan pemanenan atau penebangan, pengayaan, pemeliharaan dan pemasaran.

Secara normatif dalam pemberian IUPHHK tidak ada perintah dari Undang-Undang bahwa keberadaan tanah ulayat diakui dan dihormati. Hal ini tentu beranjak dari sikap UU Kehutanan itu sendiri bahwa status hutan hanya dua yaitu hutan negara dan hutan hak. ${ }^{36}$ UU No. 41 Tahun 1999 tidak memberikan status tertentu kepada hutan ulayat. Bahkan, hutan ulayat dianggap sebagai bagian dari hutan negara. Pengakuan terhadap keberadaan hutan adat seperti itu pun tidak bisa serta merta, melainkan harus berdasarkan penetapan oleh pemerintah (Menteri Kehutanan). Menteri Kehutanan tidak mau tahu jika secara de facto di lapangan terdapat hutan ulayat nagari sebagaimana yang telah dikemukakan di atas. Secara faktual, ternyata kawasan seluas 28.480 HA tersebut berada di atas tanah ulayat dari 9 (sembilan) nagari, sehingga pengusaha (PT AMT) menemui kesulitan dalam menjalankan usahanya. Pendirian ini sebetulnya tidak saja merugikan MHA tetapi juga pengusaha itu sendiri. Kepastian hukum bagi pengusaha menjalankan usahanya menjadi terancam, padahal dia telah memenuhi berbagai kewajiban kepada negara, seperti iuran kehutanan, provisi hutan, dana reboisasi, dan sebagainya. Menteri akan lepas tangan kalau ternyata di lapangan pengusaha menemui hambatan dengan keberadaan tanah ulayat. Kalau sejak pemberian izin pemerintah sudah mengakui keberadaan tanah ulayat tentu kompensasi terhadap masyarakat hukum adat pemegang ulayat harus diperhitungkan sebagai beban biaya modal usaha bagi pengusaha. Seyogianya sebagian biaya yang dikeluarkan oleh

\footnotetext{
35 Kurnia Warman, dkk., 2010, Pemulihan Tanah Ulayat, Perspektif Pemangku Kepentingan di Sumatera Barat, Penerbit HuMa dan Qbar, Jakarta dan Padang, hlm. 78-80.

36 Pasal 5 ayat (1) Undang-Undang Nomor 41 Tahun 1999 tentang Kehutanan (Lembaran Negara Republik Indonesia Tahun 1999 Nomor 167, Tambahan Lembaran Negara Republik Indonesia Nomor 3888).
} 
pengusaha kepada pemerintah dialokasikan sebagai kompensasi terhadap tanah ulayat.

Konsisten dengan pendirian UU No. 41 Tahun 1999, PP No. 6 Tahun 2007 juga menyatakan bahwa pemberian IUPHHK tidak memerlukan pelepasan hak dari masyarakat hukum adat. Ketentuan ini tidak saja sebagai penegasan sikap pemerintah bahwa hutan adat tidak diakui dalam pemberian izin usaha di bidang kehutanan. Pasal ini juga semakin membuktikan resistensi Kementerian Kehutanan terhadap otonomi daerah, karena kewenangan pemberian izin usaha kehutanan merupakan kewenangan pemerintah pusat (Menteri).

Terkait dengan status hutan adat di dalam UU No. 41 Tahun 1999, Mahkamah Konstitusi Republik Indonesia telah memberikan momentum besar terhadap pengakuan hutan adat, melalui Putusan Mahkamah Konstitusi No. 35/PUU-X/2012. Mahkamah Konstitusi (Selanjutnya disebut MK) melalui amar putusannya menyatakan bahwa Pasal 5 ayat (1) UU No. 41 Tahun 1999 bertentangan dengan UUD dan tidak mempunyai kekuatan mengikat sepanjang tidak dimaknai "Hutan negara sebagaimana dimaksud pada ayat (1) huruf a, tidak termasuk hutan adat". Terkait dengan itu, Penjelasan Pasal 5 ayat (1) juga dinyatakan bertentangan dengan UUD dan tidak mempunyai kekuatan mengikat. Berikutnya Pasal 5 ayat (2) juga bertentangan dengan UUD dan tidak mempunyai kekuatan mengikat.

Pasca Putusan MK tersebut, timbul pertanyaan bagaimana status hutan adat sekarang? Apakah hutan adat merupakan entitas tersendiri yang berbeda dari hutan negara dan hutan hak? Hal ini tidak dimuat di dalam amar Putusan MK. Tidak dimuatnya ketentuan ini di dalam amar Putusan MK merupakan konsekuensi dari kewenangan MK yang tidak boleh membuat norma baru. MK hanya berwenang membatalkan dan menyatakan norma atau pasal yang sudah tidak berlaku atau tidak mempunyai kekuatan berlaku. Ketentuan seperti ini merupakan konsekuensi dari kedudukan MK hanya sebagai negative legislator, bukan seperti Dewan Perwakilan Rakyat (DPR) yang berkedudukan sebagai legislator atau positive legislator.

Kembali ke pertanyaan, bagaimana status hutan adat (ulayat) pasca Putusan Mahkamah Konstitusi No. 35 tersebut. Amar putusan hanya menyatakan tidak berlaku Pasal 5 ayat (2) yang menyatakan bahwa hutan negara dapat berupa hutan adat. Artinya hutan adat tidak lagi termasuk hutan negara. Sikap MK terhadap status hutan adat dapat dilihat di dalam pertimbangan hukum putusannya. Jika ditelusuri pandangan MK terhadap hutan ternyata hutan adat bukanlah merupakan entitas tersendiri, melainkan sebagai bagian dari hutan hak. Sikap ini dapat dilihat di dalam halaman 179 Putusan Mahkamah Konstitusi No. 35/PUU-X/2012. ${ }^{37}$ MK menyatakan bahwa "kategori hutan hak di dalamnya haruslah dimasukkan hutan adat". Jadi menurut MK hutan adat termasuk ke dalam hutan hak.

Bagaimana implikasi putusan ini terhadap status izin usaha kehutanan yang telah diberikan dan sedang berjalan? Karena Putusan MK bukanlah membuat peraturan (positive legislator), tetapi hanya menyatakan berlaku tidaknya ketentuan UU (negative legislator), untuk itu perlu perubahan UU No. 41 Tahun 1999 sesuai Putusan MK. Putusan MK bukanlah penyelesaian sengketa konkrit yang memerlukan eksekusi di lapangan seperti perkara perdata. Terkait dengan pemberian IUPHHK dalam pemanfaatan tanah ulayat untuk usaha kehutanan, kedudukan Putusan MK ini sangat penting. Putusan ini tentu berdampak terhadap prosedur pemberian izin. Sebelum adanya Putusan MK ini pemberian IUPHHK tidak memperhitungkan keberadaan hutan adat atau hutan ulayat, seperti yang terjadi dengan pemberian IUPHHK bagi PT AMT pada Tahun 2000. Jika pemberian IUPHHK terhadap PT AMT diberikan sekarang tentu akan lain kenyataannya. Karena Putusan MK ini menyatakan bahwa hutan adat itu sebagai hutan hak tentu pemberian IUPHHK di atas tanah ulayat nagari

37 Putusan Mahkamah Konstitusi Nomor 35/PUU-X/2012 perihal perkara Pengujian Undang-Undang Nomor 41 Tahun 1999 tentang Kehutanan terhadap Undang-Undang Dasar Negara Republik Indonesia Tahun 1945, tanggal 16 Mei 2013. 
harus berdasarkan pelepasan hak dari masyarakat hukum adatnya terlebih dahulu. Dengan adanya persyaratan pelepasan hak maka mau tidak mau pengusaha harus membuat kesepakatan dengan masyarakat pemegang ulayat. Kesepakatan inilah yang nantinya melahirkan hubungan hukum dalam pemanfaatan tanah ulayat untuk usaha kehutanan.

\section{Kesimpulan}

Pembangunan perkebunan di Sumatera Barat pada umumnya dilaksanakan dengan cara pemberian Hak Guna Usaha (HGU) kepada pengusaha. Akibatnya, hubungan hukum antara MHA dan pengusaha tidak merupakan hubungan langsung. Pada umumnya pola hubungan hukum dalam pemanfaatan tanah ulayat untuk usaha perkebunan terjadi dalam tiga tahap, yaitu: (1) penyerahan tanah ulayat oleh MHA kepada bupati sebagai kepala daerah; (2) penyerahan tanah ulayat oleh bupati kepada pengusaha; dan (3) pemberian hak guna usaha oleh negara kepada pengusaha. Setelah negara memberikan HGU kepada pengusaha, maka sebetulnya hubungan hukum antara MHA dan pengusaha menjadi kabur. Hubungan hukum pemanfaatan tanah ulayat untuk usaha pengelolaan sumberdaya air dilaksanakan oleh pemerintah nagari dengan pemerintah daerah. Proses terjadinya hubungan hukum dilaksanakan melalui proses hukum administrasi, tidak melalui perjanjian (hukum perdata). Walaupun hubungan hukum MHA nagari dengan pemerintah daerah tidak begitu jelas, namun dengan adanya pengakuan terhadap keberadaan ulayat nagari, ketidakjelasan tersebut tidak terlalu dipersoalkan. Pemanfaatan sumberdaya air sebagai obyek ulayat MHA tidak berpedoman kepada UU No. 7 Tahun 2004, tetapi berdasarkan UU No. 32 Tahun 2004 yang mengatur pemerintah daerah. Hubungan hukum antara pengusaha dan MHA dalam pemanfaatan tanah ulayat untuk usaha pertambangan juga bersifat nyata. Hal ini memungkinkan kepada kedua pihak untuk menyepakati hal-hal sesuai dengan keinginan mereka. Pemberian IUP tidak mensyaratkan pelepasan hak atas tanah ulayat dan pelaksanaannya juga tidak mengharuskan adanya hak atas tanah tertentu. Pengusaha pemegang IUP juga tidak terlalu berkepentingan dengan adanya hak atas tanah tertentu. Pengusaha juga tidak membutuhkan sertipikat tanah untuk dijadikan sebagai agunan kredit perbankan. Secara faktual pada umumnya pengusaha pertambangan tidak membutuhkan hak tanggungan atas tanahnya. Pola hubungan hukum dalam pemanfaatan tanah ulayat untuk usaha kehutanan tidak terjadi sebagaimana mestinya menurut hukum yang berlaku. Pengakuan konstitusi terhadap keberadaan MHA dan hak ulayatnya belum bisa diwujudkan dalam pemberian IUPHHK. Kesepakatan yang ditempuh pengusaha dengan MHA dalam menjalankan usahanya hanya sekedar upaya pendekatan agar usahanya bisa berjalan. Hal ini terjadi karena izin usaha kehutanan memang tidak mensyaratkan adanya pelepasan hak tanah ulayat. Pemberian IUPHHK tidak memerlukan adanya hak atas tanah. Akibatnya, dalam pemanfaatan tanah ulayat untuk usaha kehutanan seperti IUPHHK tidak ada hubungan hukum antara pemegang ulayat dengan pengusaha.

\section{DAFTAR PUSTAKA}

\section{A. Buku}

Arikunto, Suharsimi, 2006, Prosedur Penelitian: Suatu Pendekatan Praktik, Rineka Cipta, Jakarta.

Bakri, Muhammad, 2007, Hak Menguasai Tanah oleh Negara: Paradigma Baru untuk Reformasi Agraria, Citra Media, Yogyakarta.
Dirdjosisworo, Soedjono, 2010, Pengantar Ilmu Hukum, Raja Grafindo Persada, Jakarta.

Datoek Toeah, 1986, Tambo Alam Minangkabau, Pustaka Indonesia, Bukittinggi.

Harsono, Boedi, 2005, Hukum Agraria Indonesia: Sejarah Pembentukan Undang-Undang Pokok Agraria, Isi, dan Pelaksanaannya, 
Djambatan, Jakarta.

Marzuki, Peter Mahmud, 2012, Pengantar Ilmu Hukum, Kencana Prenada Media Group, Jakarta.

Mertokusumo, Sudikno, 2002, Hukum Acara Perdata Indonesia, Liberty, Yogyakarta.

Miko, Alfan (Ed.), 2006, Pemerintahan Nagari dan Tanah Ulayat, Andalas University Press, Padang.

Salim H.S., 2012, Hukum Pertambangan di Indonesia, Rajawali Press, Jakarta.

Sumardjono, Maria S.W., 1982, Puspita Serangkum Aneka Masalah Hukum Agraria, Andi Offset, Yogyakarta.

2005, Kebijakan Pertanahan: Antara Regulasi dan Implementasi, Kompas Media Nusantara, Jakarta.

Taneko, Soleman B., 1987, Hukum Adat: Suatu Pengantar Awal dan Prediksi Masa Mendatang, Eresco, Bandung.

Warman, Kurnia, dkk., 2010, Pemulihan Tanah Ulayat, Perspektif Pemangku Kepentingan di Sumatera Barat, Penerbit HuMa, Qbar, Jakarta dan, Padang.

\section{B. Hasil Penelitian}

Hanifzar, 2010, Penyelesaian Sengketa Tanah Ulayat di Kabupaten Pasaman Barat (Studi Sengketa Tanah Perkebunan PT Gersindi Minang Plantation), Tesis, Program Pascasarjana Program Sudi Ilmu Hukum Universitas Andalas, Padang.

Novrial, 2012, Pemanfaatan Tanah Ulayat untuk Perkebunan di Nagari Tapan Kabupaten Pesisir Selatan, Tesis, Program Magister Kenotariatan Fakultas Hukum Universitas Andalas, Padang.

Susanti, Afni Gusni, 2013, Pelaksanaan Perjanjian Pembangunan dan Pengelolaan Perkebunan Kelapa Sawit dengan Pola Kemitraan/Inti Plasma antara Ninik Mamak Bawan dengan PT AMP Plantation di Tanah Ulayat Bawan
Kecamatan Ampek Nagari Kabupaten Agama, Tesis, Program Pascasarjana Fakultas Hukum Universitas Andalas, Padang.

\section{Sumber Internet}

KPP-KASRI, "Konflik Tenurial antara Masyarakat dan Alam", http://kkpkasri.blogspot. com/2011/10/konflik-tenurial-antaramasyarakat-alam.html, diakses 5 November 2013.

\section{Peraturan Perundang-Undangan}

Undang-Undang Nomor 5 Tahun 1960 tentang Peraturan Dasar Pokok-Pokok Agraria (Lembaran Negara Republik Indonesia Tahun 1960 Nomor 104; Tambahan Lembaran Negara Nomor 2043).

Undang-Undang Nomor 41 Tahun 1999 tentang Kehutanan (Lembaran Negara Republik Indonesia Tahun 1999 Nomor 167, Tambahan Lembaran Negara Republik Indonesia Nomor 3888).

Undang-Undang Nomor 18 Tahun 2004 tentang Perkebunan (Lembaran Negara Republik Indonesia Tahun 2004 Nomor 85, Tambahan Lembaran Negara Republik Indonesia Nomor 4411).

Peraturan Pemerintah Nomor 16 Tahun 2005 tentang Pengembangan Sistem Penyediaan Air Minum (Lembaran Negara Republik Indonesia Tahun 2005 Nomor 33, Tambahan Lembaran Negara Republik Indonesia Nomor 4490).

Surat Keputusan Menteri Kehutanan Nomor 82/ Kpts-II/2000, tanggal 22 Desember 2000.

Surat Keputusan Nomor FA/N/024/IV/1980, tanggal 21 April 1980 dan Surat Keputusan Menteri Pertanian No. 624/Kpts/Um/1980, tanggal 26 Agustus 1980.

Surat Keputusan Bupati Solok Nomor 540-3062011 tentang Izin Usaha Pertambangan Eksplorasi. 
E. Putusan Pengadilan

Putusan Mahkamah Konstitusi Nomor 35/ PUU-X/2012 perihal Perkara Pengujian Undang-Undang Nomor 41 Tahun 1999 tentang Kehutanan terhadap Undang-Undang Dasar Negara Republik Indonesia Tahun 1945, tanggal 16 Mei 2013. 